\title{
Co-ordinate Regulation of Enzymes Involved in Ornithine Metabolism and its Relation to Sporophore Morphogenesis in Coprinus cinereus
}

\author{
By JULIET O. EWAZE, DAVID MOORE AND GEORGE R. STEWART \\ Department of Botany, The University, Manchester M13 9PL
}

(Received 17 February 1978)

\begin{abstract}
Arginine synthesis and urea formation via the ornithine cycle occurred in sporophore cap and stipe of Coprinus cinereus. Although urease was found at high activity in mycelium and stipe, it was not detectable in extracts of cap tissue, but arginine biosynthesis was specifically amplified during development of the cap as judged from metabolism of isotopically labelled substrates and increased enzyme activities. Four enzymes, NADP-linked glutamate dehydrogenase, glutamine synthetase, ornithine acetyltransferase and ornithine carbamoyltransferase, were considerably derepressed in developing caps while remaining low (or declining) in activity in the stipes supporting those caps. Co-ordinate regulation of these enzymes could also be demonstrated in vegetative mycelium subjected to particular synthetic growth media. Arginine, alanine and glutamate accumulated in the cap as a result of amplified arginine biosynthesis. A greater than twofold increase in the quantity of urea in the cap was also evident during development, although the concentration of urea remained essentially unchanged. A causal relationship between urea accumulation and water influx into developing cap tissues is suggested. The inflation of the gill hymenium cells accounts for the 'umbrella-like' cap expansion that characterizes Coprinus spp.
\end{abstract}

\section{INTRODUCTION}

The NADP-linked glutamate dehydrogenase of Coprinus cinereus is derepressed to a considerable extent during development of the sporophore, but only in cap tissues (Stewart \& Moore, 1974). The cause of this derepression is unknown. Analysis of factors influencing the regulation of glutamate dehydrogenase in mycelium showed that catabolite repression/derepression plays a major role, though regulation is complex and involves more than one molecule (Fawole \& Casselton, 1972; Stewart \& Moore, 1974). The function of the enzyme is also obscure, particularly as high activities of a NAD-linked glutamate dehydrogenase can be demonstrated in both cap and stipe. Involvement of glutamate dehydrogenase activity in a central part of carbon metabolism is implied by the observation that an inoperative 2-oxoglutarate dehydrogenase in the tricarboxylic acid cycle is by-passed through the glutamate decarboxylation loop (Moore \& Ewaze, 1976). Some relation with nitrogen metabolism is also to be expected and there have been repeated indications of a connection between glutamate dehydrogenase, particularly the NADP-linked enzyme, and the urea cycle (Stewart \& Moore, 1974; Al-Gharawi \& Moore, 1977).

In this paper we report on three further enzymes which, like the NADP-linked glutamate dehydrogenase, have high and increasing activities in the cap but low and decreasing activities in the stipe. These enzymes contribute to arginine and urea synthesis, and the latter may have a specific morphogenetic function. This system of enzymes also appears to be co-ordinately regulated. 


\section{METHODS}

Organism. A dikaryotic culture (stock number BC9/6,6 $\times$ H1) of the basidiomycete Coprinus cinereus (Schaeff. ex Fr.) S. F. Gray was used for experiments on sporophore production. The prototrophic strain BC9/6,6 was used to study the effects of the medium constituents on enzyme activity in monokaryotic mycelium.

Conditions of culture. Most of the work with sporophores used cultures grown on sterilized horse dung (Moore \& Ewaze, 1976), but to facilitate comparative analysis of sporophores and their parent mycelia some cultures were grown in unstirred liquid maltose-CM medium (Stewart \& Moore, 1974). Where reference is made to different stages in sporophore development, the stages were recognized using the criteria detailed by Stewart \& Moore (1974). Differences in the timing of developmental events between cultures grown on dung and those grown on maltose-CM are noted in the legend to Fig. 2. Monokaryon cultures were grown in $300 \mathrm{ml}$ of liquid medium in 1 litre conical flasks incubated at $37^{\circ} \mathrm{C}$ on an orbital shaker operating at $120 \mathrm{rev} . \mathrm{min}^{-1}$. The medium consisted of SNC basa lsolution (Al-Gharawi \& Moore, 1974) to which appropriate carbon and nitrogen sources were added. Monokaryon cultures were inoculated with'about $10^{7}$ oidia and were harvested by filtration through Whatman GF/A filter discs after 3 to $7 \mathrm{~d}$ incubation (Fig. 6). Mycelia were also transferred from the medium in which they were initially grown into another experimental medium (Fawole \& Casselton, 1972). In all experiments, the initial medium consisted of SNC plus $10 \mathrm{mm-glucose,}$ $30 \mathrm{~mm}-\mathrm{NH}_{4} \mathrm{Cl}$ and $1 \%$ (w/v) Bacto-Casamino acids (Difco). The mycelium was harvested after $4 \mathrm{~d}$ incubation by centrifuging in sterile $250 \mathrm{ml}$ bottles using an MSE HS18 centrifuge $\left(2500 \mathrm{~g}, 10 \mathrm{~min}, 25^{\circ} \mathrm{C}\right)$. The supernatant was discarded and the pellet was resuspended in $250 \mathrm{ml}$ of sterile deionized water to wash the mycelium. The mycelium was re-sedimented by centrifuging, the supernatant was discarded and the pellet was resuspended in $300 \mathrm{ml}$ of transfer medium prior to incubation on the orbital shaker. The mycelium was finally harvested by filtration through GF/A filters. The transfer medium usually consisted of SNC plus $100 \mathrm{~mm}$-sodium pyruvate (without added nitrogen source). In some experiments (Table 5), ornithine replaced or was used in addition to the pyruvate.

Enzyme assay. Tissue was ground with extraction buffer (100 mM-Tris/HCl plus $1 \mathrm{~mm}-\mathrm{EDTA}, \mathrm{pH} 8 \cdot 5)$ and acid-washed sand in an ice-cold mortar. The homogenate was filtered through $25 \mathrm{~mm}$ diam. GF/A filter discs and the filtrate was desalted with a $140 \times 10 \mathrm{~mm}$ column of Sephadex G-25. The desalted extracts were used without further treatment. Spectrophotometric assays were done at $30^{\circ} \mathrm{C}$ in a Pye Unicam SP1800B spectrophotometer fitted with an external chart recorder. Radioactivity was measured by a Packard model 2420 Tri-Carb LS spectrometer after dispersal of the sample in appropriate scintillation fluid.

The NAD- and NADP-linked glutamate dehydrogenases were assayed using the methods of Al-Gharawi \& Moore (1974), and malate dehydrogenase was assayed using the method described by Moore \& Ewaze (1976). Other enzyme assays were derived from those described in the literature by determination of optimal pH and substrate concentration. The following assay mixtures were found to be best for Coprinus extracts. Kinetic constants are listed in Table 1. (a) Alanine:2-oxoglutarate aminotransferase, EC 2.6.1.2: $30 \mathrm{~mm}-\mathrm{L}$-alanine, $6 \mathrm{~mm}$-2-oxoglutarate, $0 \cdot 156 \mathrm{~mm}-\mathrm{NADH}$ and 70 units (desalted) lactate dehydrogenase $\mathrm{ml}^{-1}$, all dissolved in $100 \mathrm{~mm}$-potassium phosphate buffer, $\mathrm{pH} \mathrm{7.5}$; absorbance at $340 \mathrm{~nm}$ was followed spectrophotometrically. (b) Arginase, EC 3.5.3.1: $50 \mathrm{~mm}$-L-arginine and $1 \mathrm{~mm}-\mathrm{MnCl}_{2}$ dissolved in $25 \mathrm{~mm}$-glycine/ $\mathrm{NaOH}$ buffer, pH 9; the reaction was allowed to proceed for $5 \mathrm{~min}$ at $37^{\circ} \mathrm{C}$ and was then terminated by adding 5 vol. of $5 \%(\mathrm{w} / \mathrm{v})$ trichloroacetic acid (TCA); the ornithine produced was determined according to Chinard (1952). (c) Asparagine synthetase, EC 6.3.1.1: $1 \mathrm{~mm}$-aspartate, $800 \mathrm{~mm}$-hydroxylamine, $10 \mathrm{~mm}$ ATP and $12 \mathrm{mM}-\mathrm{MnCl}_{2}$ dissolved in a solution of $100 \mathrm{~mm}-\mathrm{Tris}$, and the pH adjusted to 6.8 with $8 \mathrm{M}-\mathrm{KOH}$; the reaction was allowed to proceed for $10 \mathrm{~min}$ at $37^{\circ} \mathrm{C}$ and was then terminated by adding 3 vol. of ferric chloride reagent (Ravel et al., 1962); absorbance at $540 \mathrm{~nm}$ was measured after removal of precipitated protein by centrifuging. (d) Aspartate:2-oxoglutarate aminotransferase, EC 2.6.1.1:25 mM-aspartate, 5 mM-2-oxoglutarate, $0 \cdot 156 \mathrm{mM} \mathrm{NADH}$ and 70 units (desalted) malate dehydrogenase $\mathrm{ml}^{-1}$, all dissolved in $100 \mathrm{~mm}$-potassium phosphate buffer, $\mathrm{pH} \mathrm{7.5}$; absorbance at $340 \mathrm{~nm}$ was followed spectrophotometrically.

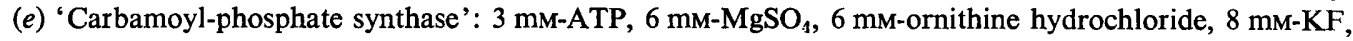
$8 \mu \mathrm{g}$ ornithine carbamoyltransferase $\mathrm{ml}^{-1}, 10 \mathrm{mM}-\mathrm{L}-\mathrm{glutamine}$ and $10 \mathrm{mM}-\mathrm{KH}^{14} \mathrm{CO}_{3} \quad\left(=1 \mu \mathrm{Ci} \mathrm{ml} \mathrm{m}^{-1}\right)$ dissolved in 100 mm-potassium phosphate buffer, $\mathrm{pH} \mathrm{7.5}$. The assay was the same as that described by Levenberg (1962) except for the concentrations of glutamine and $\mathrm{KH}^{14} \mathrm{CO}_{3}$; it was carried out in a closed vessel for $60 \mathrm{~min}$ at $28^{\circ} \mathrm{C}$ and was terminated by injecting a 2:1 mixture of ethanol and $2 \mathrm{M}-\mathrm{HCl}$. Acid-labile ${ }^{14} \mathrm{CO}_{2}$ was trapped in saturated $\mathrm{Ba}(\mathrm{OH})_{2}$; acid-fast ${ }^{14} \mathrm{C}$ (presumed to be citrulline) was measured by adding $100 \mu \mathrm{l}$ of the acidified reaction mixture to a scintillation vial containing $15 \mathrm{ml}$ of a mixture consisting of 1 litre toluene, $500 \mathrm{ml}$ Triton X-100, $5 \mathrm{~g}$ 2,5-diphenyloxazole and 0.3 g 1,4-di-2(5-phenyloxazolyl)benzene. The identity of this enzyme is uncertain; ${ }^{14} \mathrm{CO}_{2}$ fixation occurred in the presence of either glutamine or an ammonium salt (Table 6). ( $f$ ) Glutamine synthetase, EC 6.3.1.2: $100 \mathrm{~mm}$-L-glutamine, $20 \mathrm{~mm}$-sodium

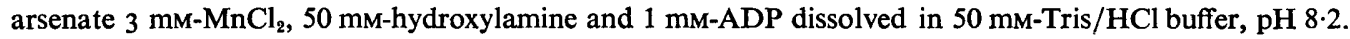




\section{Table 1. Kinetic constants of some enzymes involved in nitrogen metabolism in Coprinus}

\begin{tabular}{|c|c|c|c|}
\hline Enzyme & Substrate & $K_{\mathrm{m}}$ & $V_{\max }$ \\
\hline Glutamine synthetase & Glutamine & $34 \cdot 5$ & $3 \cdot 80$ \\
\hline \multirow[t]{2}{*}{ Ornithine carbamoyltransferase } & Ornithine & $2 \cdot 4$ & 1.90 \\
\hline & Carbamoyl phosphate & 0.9 & $1 \cdot 50$ \\
\hline \multirow{2}{*}{$\begin{array}{l}\text { Aspartate: } 2 \text {-oxoglutarate } \\
\text { aminotransferase }\end{array}$} & Aspartate & $6 \cdot 25$ & $2 \cdot 27$ \\
\hline & 2-Oxoglutarate & 0.72 & 1.85 \\
\hline \multirow{2}{*}{$\begin{array}{l}\text { Alanine: } 2 \text {-oxoglutarate } \\
\text { aminotransferase }\end{array}$} & Alanine & $16 \cdot 0$ & $1 \cdot 47$ \\
\hline & 2-Oxoglutarate & $2 \cdot 5$ & 1.05 \\
\hline \multirow{3}{*}{$\begin{array}{l}\text { Arginase } \\
\text { Ornithine:2-oxoacid aminotransferase }\end{array}$} & Arginine & $100 \cdot 0$ & $1 \cdot 60$ \\
\hline & Ornithine & $2 \cdot 4$ & 0.025 \\
\hline & 2-Oxoglutarate & $6 \cdot 25$ & 0.083 \\
\hline \multirow[t]{2}{*}{ Ornithine acetyltransferase } & $N$-Acetylornithine & $2 \cdot 6$ & 0.064 \\
\hline & Glutamate & $4 \cdot 5$ & 0.063 \\
\hline Asparagine synthetase & Aspartate & 1.05 & 0.23 \\
\hline
\end{tabular}

The procedure followed that of Woolfolk et al. (1966); after $5 \mathrm{~min}$ incubation at $37^{\circ} \mathrm{C}$ the reaction was stopped by adding $0.25 \mathrm{vol}$. of ferric chloride reagent; absorbance at $540 \mathrm{~nm}$ was measured after removal of precipitated protein. $(g)$ Ornithine acetyltransferase, EC 2.3.1.35:6 mM- $N$-acetyl-L-ornithine and $12 \mathrm{mM}$ L-glutamate dissolved in $100 \mathrm{~mm}$-Tris/ $\mathrm{HCl}$ buffer, $\mathrm{pH}$ 7.5. The procedure followed that of Staub \& Denes (1966); after $10 \mathrm{~min}$ incubation at $37^{\circ} \mathrm{C}$ the reaction was stopped by adding $3 \mathrm{vol}$. of ninhydrin reagent; the amount of ornithine formed was determined by the method of Vogel \& Bonner (1956). ( $h$ ) Ornithine carbamoyltransferase, EC 2.1.3.3:5 mM-carbamoyl phosphate and $10 \mathrm{~mm}$-ornithine dissolved in $100 \mathrm{~mm}$ Tris/ $\mathrm{HCl}$ buffer, $\mathrm{pH} 8.5$; after $15 \mathrm{~min}$ incubation at $37^{\circ} \mathrm{C}$ the reaction was stopped by adding 0.25 vol. of $5 \% \mathrm{TCA}$; precipitated protein was removed by centrifuging and the supernatant was assayed for citrulline (Archibald, 1944). (i) Ornithine:2-oxoacid aminotransferase, EC 2.6.1.13: $20 \mathrm{mM}$-L-ornithine, $10 \mathrm{mM}$-2oxoglutarate and $61 \mu \mathrm{M}$-pyridoxal phosphate dissolved in $100 \mathrm{mM}$-sodium phosphate buffer, $\mathrm{pH} 7.8$; after $30 \mathrm{~min}$ incubation at $37^{\circ} \mathrm{C}$ the reaction was stopped by adding 1 vol. of $10 \%$ TCA followed by 2 vol. of a solution of $o$-aminobenzaldehyde (Vogel \& Kopac, 1960) to allow determination of the reaction product. (j) Urease, EC 3.5.1.5: the assay mixture contained only $5 \mathrm{mM}$-urea (containing $\left[{ }^{14} \mathrm{C}\right]$ urea at $0.08 \mu \mathrm{Ci} \mathrm{ml}^{-1}$ ) dissolved in $100 \mathrm{~mm}$-Tris/ $\mathrm{HCl}$ buffer, $\mathrm{pH}$. The reaction was carried out in a closed vessel containing a separate cup charged with $150 \mu$ l of methyl benzethonium hydroxide (Hyamine hydroxide, Sigma) solution to absorb the released ${ }^{14} \mathrm{CO}_{2}$. After $30 \mathrm{~min}$ incubation at $37{ }^{\circ} \mathrm{C}$ the reaction mixture was acidified by injecting $0.25 \mathrm{vol}$. of $2.5 \mathrm{M}-\mathrm{H}_{2} \mathrm{SO}_{4}$, and a further $60 \mathrm{~min}$ was allowed for complete solution of $\mathrm{CO}_{2}$ into the Hyamine hydroxide. The vessel was then opened and the Hyamine hydroxide was transferred to a vial containing $15 \mathrm{ml}$ of the scintillation fluid described above. Since different sporophore tissues differed enormously in the activity of urease measured with this assay (see text), attempts were made to detect urea amidolyase activity (Roon \& Levenberg, 1968, 1972). Extracts were made of monokaryotic and dikaryotic mycelia grown with ammonium tartrate or urea or a mixture of the two as nitrogen sources, and of sporophore caps and stipes of all developmental ages, but in no case did addition of ATP and/or mono- and divalent metal ions to the above assay increase $\mathrm{CO}_{2}$ evolution over the level observed in the normal urease assay. We therefore concluded, following Darbyshire (1974), that the enzyme involved in urea breakdown in this organism is urease. Other enzymes with negligibly low levels of activity in Coprinus extracts, despite attempts to adapt extraction and assay methods, were: asparaginase, with a specific activity only 3 to $4 \%$ of that in guinea-pig tissues (Yellin \& Wriston, 1966); arginine deiminase, with a specific activity less than $1 \%$ of that recorded for mycoplasma (Schimke, 1970); and glutaminase, which had a specific activity less than $1 \%$ of that recorded in yeast (Abdumalikov \& Nikolaev, 1967).

Enzyme reactions were initiated by adding the cell-free extract to an amount corresponding to between 10 and $25 \%$ of the final volume of the reaction mixture. Endogenous activities were determined with reaction mixtures lacking substrate, and assays using radiochemicals were also accompanied by a control reaction mixture lacking cell-free extract. Protein concentrations were measured by the method of Lowry et al. (1951) using bovine serum albumin as a standard. Substrate concentrations were determined by use of appropriate calibration curves or, where oxidation of NADH or NADPH was recorded, by calculation, assuming a molar absorption coefficient of $6.22 \times 10^{3} 1 \mathrm{~mol}^{-1} \mathrm{~cm}^{-1}$. Enzyme activities are expressed as $\mu$ mol substrate used $\min ^{-1}$ (mg protein) $)^{-1}$ unless stated otherwise.

Chemical analyses. Amino acids, ammonia and reducing sugars were extracted by grinding frozen tissue 
in $80 \%(\mathrm{v} / \mathrm{v})$ ethanol. Amino acids and ammonia were determined as described by Orebamjo \& Stewart (1974) and reducing sugars by the method of Nelson (1944). Protein and RNA contents of the ethanolinsoluble residue were determined by a modification of the procedure described by Osborne (1962). A microKjeldahl procedure was used to estimate total nitrogen.

Estimation of individual amino acids and related compounds. Extracts were prepared by adding small amounts of fresh tissue, equivalent to about $50 \mathrm{mg}$ dry wt, to $5 \mathrm{ml}$ of boiling $80 \%$ ethanol and agitating on an orbital shaker at $26^{\circ} \mathrm{C}$ for $60 \mathrm{~min} ; 2 \mathrm{ml}$ of boiling $20 \%$ ethanol were then added and extraction was continued at $26^{\circ} \mathrm{C}$ for a further $60 \mathrm{~min}$. The process was completed by adding $2 \mathrm{ml}$ of boiling water. Finally the tissue was separated from the solution and the latter was concentrated to $1 \mathrm{ml}$. Constituents were separated by two-dimensional ascending chromatography, using ethanol/ammonia/water $(4: 1: 1$, by vol.) for $3 \mathrm{~h}$ in the first direction and 1-butanol/acetic acid/water (60:15:25, by vol.) overnight in the second direction. Ninhydrin was used to detect amino acids, Ehrlich reagent for urea and citrulline, and the aniline-xylose reagent for oxoacids. Spots were identified by means of internal standards (when radioactivity was to be measured) or by reference to mixtures of authentic compounds run simultaneously. Spots were excised and either placed directly into scintillation fluid or eluted into a solvent appropriate to the chromogenic detection agent with which they were reacted. The eluted compounds were quantified by reference to calibration curves prepared from known amounts of the authentic materials which had been subjected to the same chromatographic, elution and detection procedures.

\section{RESULTS AND DISCUSSION}

Analysis of the major nitrogenous metabolites in dikaryotic mycelia bearing sporophores showed that the concentrations of all declined as sporophores were produced (Fig. 1). For each metabolite the decline commenced at about the time that fruiting was initiated and it seemed to follow an earlier accumulation phase. Decline in content of ammonium nitrogen halted after about $10 \mathrm{~d}$ growth; thereafter the mycelial content of ammonium increased and accumulation continued for a considerable period. Samples taken after $32 \mathrm{~d}$ incubation had an ammonium content of $21.4 \mu \mathrm{mol}$ (g fresh wt) ${ }^{-1}$ compared with $17.9 \mu \mathrm{mol}$ (g fresh wt) ${ }^{-1}$ after $12 \mathrm{~d}$ incubation. In contrast, the 32 -d-old mycelium contained only $11.5 \mu \mathrm{mol} \alpha$-amino nitrogen (g fresh wt) ${ }^{-1}$ compared with $24 \mu \mathrm{mol}$ (g fresh wt) ${ }^{-1}$ after $12 \mathrm{~d}$. However, the production of ammonium is underestimated by these figures as large quantities of ammonia are excreted into the medium (Stewart \& Moore, 1974). These data demonstrated considerable catabolism of nitrogen in the fertile mycelium, but the most significant point is that the NADP-linked glutamate dehydrogenase played no part in these metabolic events. Similar analyses of sporophores (Fig. 2) also suggest that considerable metabolism of nitrogenous compounds occurs, with a marked decline in the concentrations of the measured metabolites. The amounts of $\alpha$-amino nitrogen were maintained throughout sporophore development at levels $50 \%$ higher in caps than in stipes; for ammonium nitrogen the relation was reversed, with stipes having at least twice (and up to six times) as much ammonium nitrogen as did their caps.

\section{Table 2. Specific activities of some enzymes involved in nitrogen metabolism in Coprinus mycelia and sporophores}

Mycelium was grown on maltose-CM medium. Young mycelium was harvested and assayed after $3 \mathrm{~d}$ incubation at $37^{\circ} \mathrm{C}$ in the dark. Old mycelium was incubated for a further 5 to $7 \mathrm{~d}$ in the illumination conditions described by Moore \& Ewaze (1976); it was harvested when sporophore primordia appeared, but these were removed and discarded before the mycelium was homogenized. The sporophores were grown on sterile horse dung and were at mid-stage 5 when harvested. Specific activities are expressed as $\mu \mathrm{mol}$ substrate used $\mathrm{min}^{-1}$ (mg protein $)^{-1}$.

\section{Enzyme}

Glutamine synthetase

Ornithine carbamoyltransferase

Aspartate:2-oxoglutarate aminotransferase

Alanine:2-oxoglutarate aminotransferase

$\begin{array}{cc}\begin{array}{c}\text { Young } \\ \text { mycelium }\end{array} & \begin{array}{c}\text { Old } \\ \text { mycelium }\end{array} \\ 0.09 & 0.22 \\ 0.25 & 0.34 \\ 0.57 & 0.62 \\ 0.45 & 0.12\end{array}$

Mature sporophore

\begin{tabular}{|c|c|}
\hline Cap & Stipe \\
1.78 & 0.30 \\
1.20 & 0.30 \\
1.67 & 1.20 \\
1.20 & 1.01
\end{tabular}




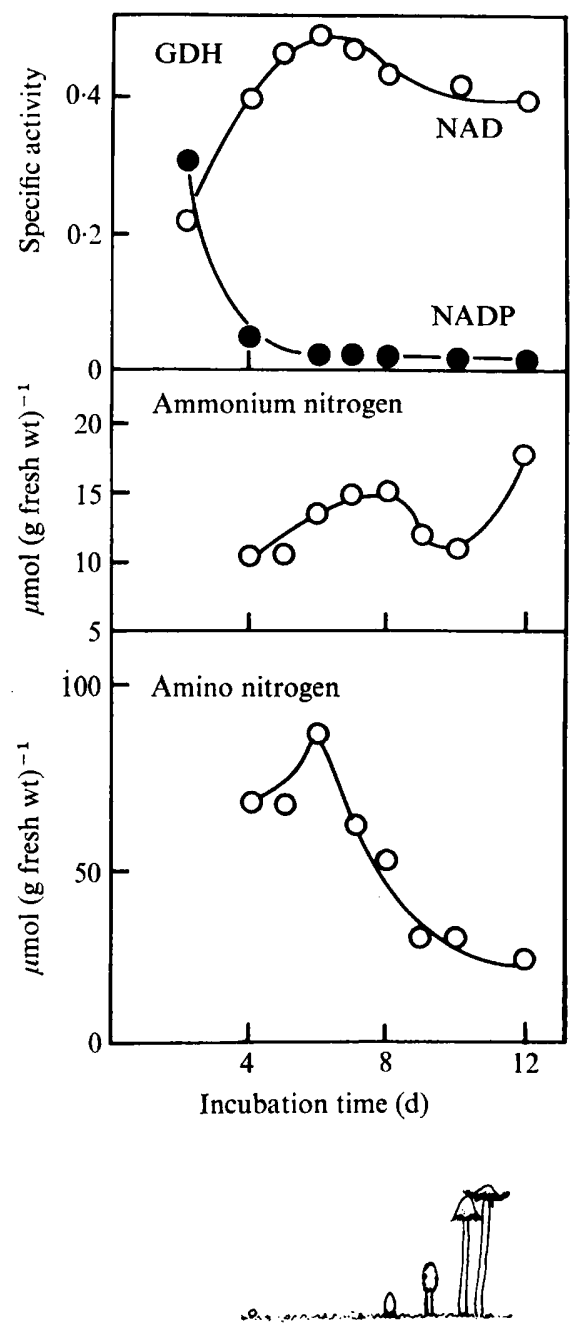

Fig. 1. Analysis of the major classes of nitrogenous metabolite in dikaryotic mycelium during the fruiting cycle of Coprinus cinereus. Mycelia were grown on liquid maltose-CM medium in the incubation and lighting conditions described by Stewart \& Moore (1974). The cartoons beneath the plots indicate the progress of sporophore development on these mycelia, but all sporophore structures were removed and separately analysed (Fig. 2) before preparation of mycelial extracts. GDH, glutamate dehydrogenase.

Qualitatively, cap, stipe and mycelium behaved similarly with respect to most of these metabolites; quantitatively, there were considerable differences and only in cap tissues did the NADP-linked glutamate dehydrogenase contribute to metabolism. However, some other enzymes which might be expected to participate in the transformations implied by these data were present in all three types of tissue (Table 2). Furthermore, operation of the urea cycle in intact sporophore tissues was demonstrated by incubation with $\left[{ }^{14} \mathrm{C}\right]$ citrulline. After $2 \mathrm{~h}$ incubation of cap tissue with $\left[{ }^{14} \mathrm{C}\right]$ citrulline, $46 \%$ of the recovered radioactivity appeared as arginine and $33 \%$ as urea; for stipe tissues, the figures were $60 \%$ and $7 \%$ respectively. The accumulation of urea in cap tissues indicated by these data is correlated with the absence of urease activity from the cap, although it occurs at high activity in the stipe (Fig. 3) and appears to be a constitutive, but catabolite repressed, enzyme in mycelium (Table 3). Among other enzymes which were assayed in sporophores at different stages of development there were some which, like NADP-linked glutamate 

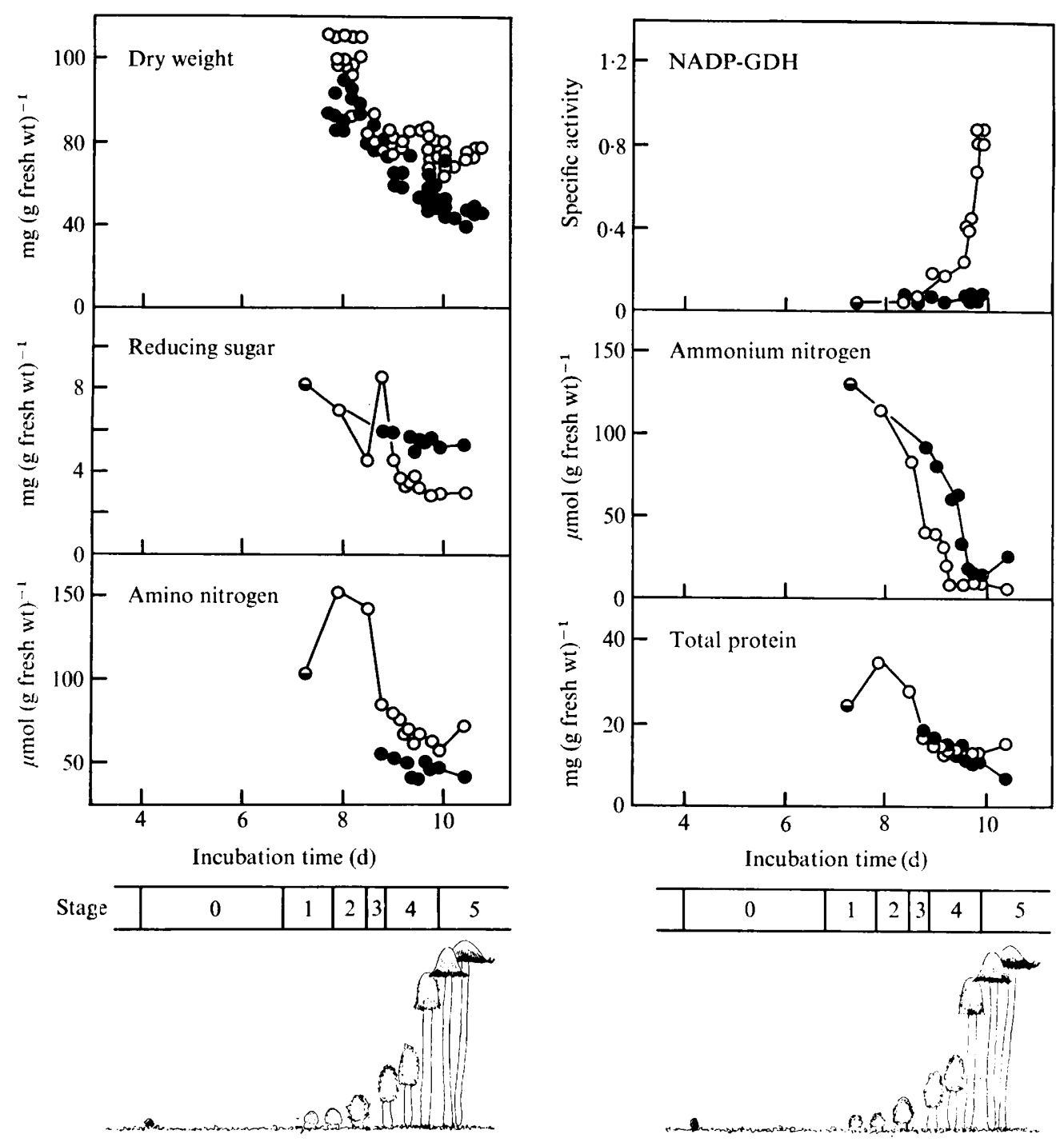

Fig. 2. Analyses of some sporophore constituents. Cap $(O)$ and stipe $(O)$ analyses were done separately. Sporophores were grown on liquid maltose-CM medium. The charts and cartoons beneath the plots show the relation between sporophore development and incubation period. On average the fruiting cycle is about $2 \frac{1}{2} \mathrm{~d}$ longer in cultures grown on maltose-CM than it is in dunggrown cultures - sporophore initials appear about $12 \mathrm{~h}$ later and then each stage is 4 to $7 \mathrm{~h}$ longer. Although dung-grown fruits are generally larger than others, the developmental process seems to be the same when judged biochemically or microscopically. We indicate the different culture conditions by giving the incubation period in days (as here) or hours (Figs 3 and 4). 'Total protein' refers to the overall content of proteinaceous material and is a different measure from the 'extractable protein' content reported by Moore \& Ewaze (1976). NADP-GDH, NADP-linked glutamate dehydrogenase.

dehydrogenase, showed high activity in the cap coupled with low activity in the stipe (Fig. 3). This similarity in regulatory behaviour was confirmed by more detailed analyses in which the different enzyme activities were all measured in each tissue homogenate (Fig. 4). The three enzymes which, like NADP-linked glutamate dehydrogenase, were derepressed in the cap were glutamine synthetase, ornithine carbamoyltransferase and ornithine acetyltransferase. Ornithine acetyltransferase catalyses the formation of ornithine 

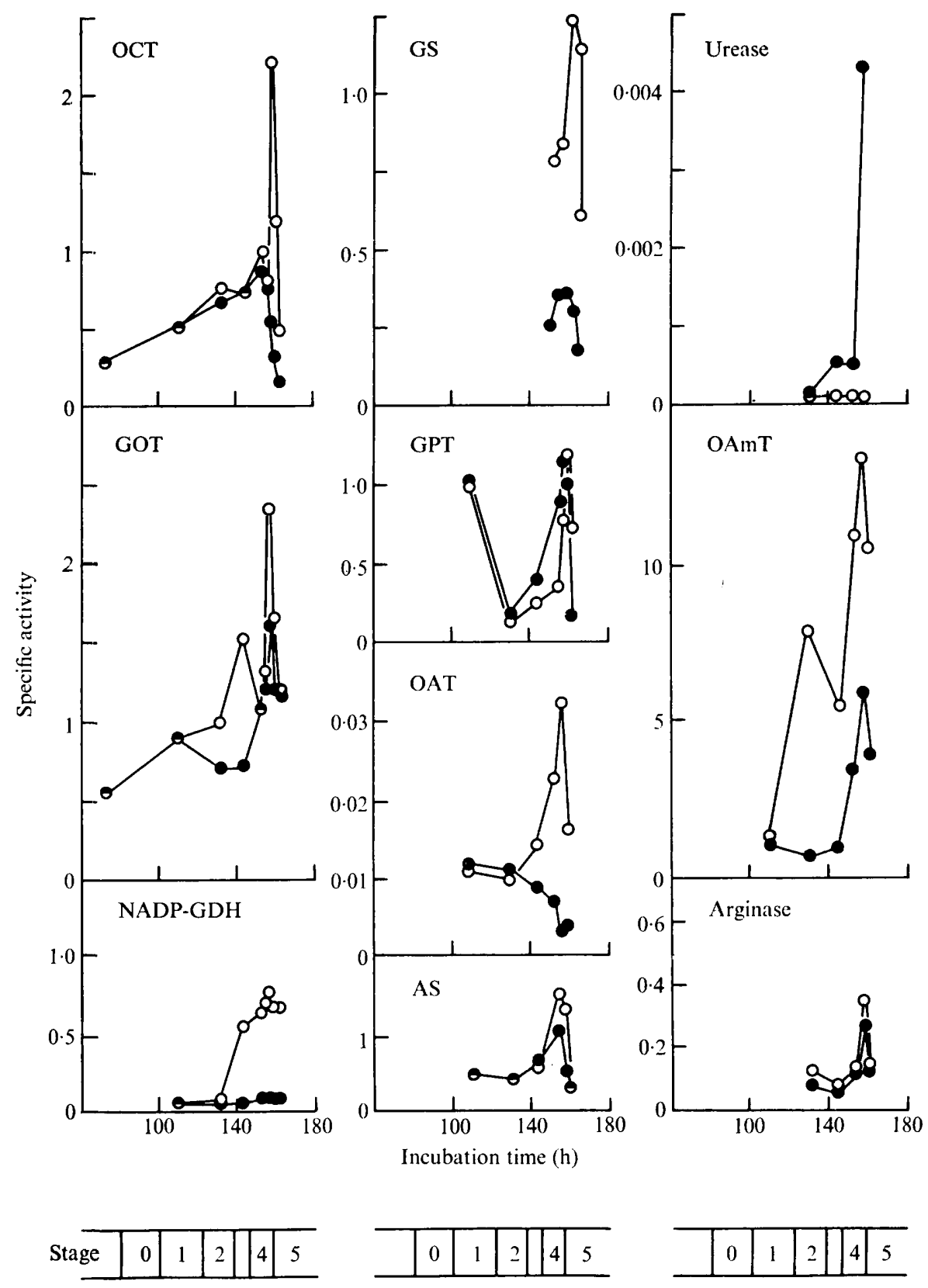

Fig. 3. Enzyme activities in sporophore caps $(O)$ and stipes (๑). Abbreviations: OCT, ornithine carbamoyltransferase; GS, glutamine synthetase; GOT, aspartate:2-oxoglutarate aminotransferase; GPT, alanine: 2-oxoglutarate aminotransferase; OAmT, ornithine:2-oxoacid aminotransferase; OAT, ornithine acetyltransferase; GDH, glutamate dehydrogenase; AS, asparagine synthetase. The charts beneath the plots indicate the developmental stages of the sporophores used to prepare the cell-free extracts. 
Table 3. Specific activity of the enzyme urease in monokaryon (strain $\mathrm{BC} 9 / 6,6)$ and dikaryon (strain BC9/6,6 $\times \mathrm{H} 1$ ) mycelia of Coprinus

Mycelium was incubated for $4 \mathrm{~d}$ at $37^{\circ} \mathrm{C}$ without agitation in liquid medium with the carbon and nitrogen sources indicated. Urease activities are expressed as $\mathrm{nmol}^{14} \mathrm{CO}_{2}$ liberated from $\left[{ }^{14} \mathrm{C}\right]$ urea $\min ^{-1}$ (mg protein) $)^{-1}$.

Carbon source

222 mm-Glucose

25 mM-Glucose

25 mM-Sodium acetate
Nitrogen source

$50 \mathrm{~mm}$-Urea

$50 \mathrm{mM}$-Ammonium tartrate

25 mM-Urea +

25 mM-Ammonium tartrate

25 mM-Urea

25 mM-Ammonium tartrate

25 mM-Urea

25 mM-Ammonium tartrate
Enzyme activity

$\begin{array}{cc}\begin{array}{c}\text { Mono- } \\ \text { karyon }\end{array} & \begin{array}{c}\text { Di- } \\ \text { karyon }\end{array} \\ 3.1 & 1.5 \\ 2.1 & 3.2 \\ 4.8 & 3.6 \\ & \\ 4.5 & - \\ 2.9 & - \\ 6.9 & - \\ 3.8 & -\end{array}$
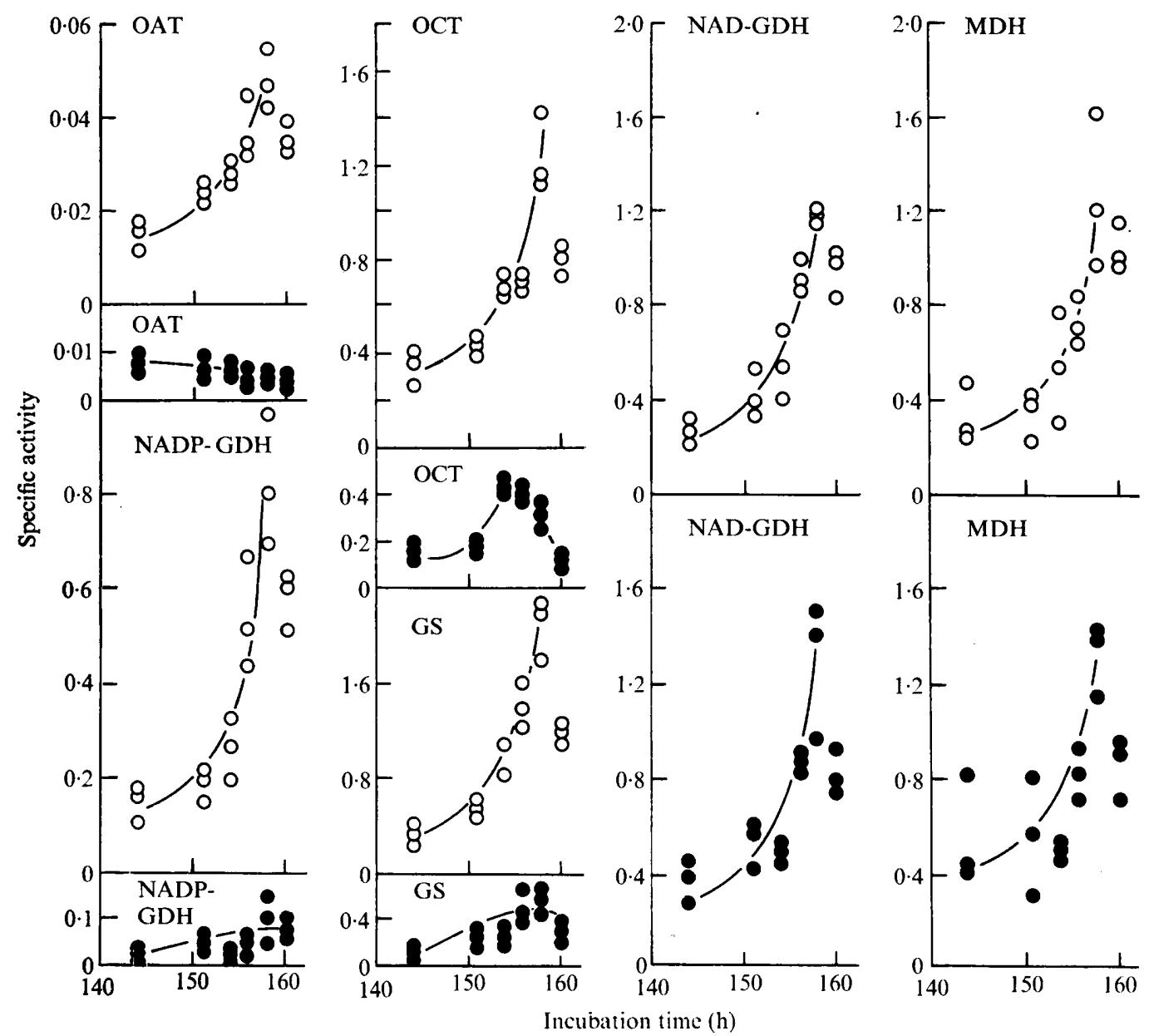

Incubation time $(\mathrm{h})$

Fig. 4. Enzyme activities in developing sporophores of Coprinus cinereus. Data differ from those presented in Fig. 3 in that assays for all six enzymes were performed with each extract. Separate homogenates were prepared from each of three sporophores judged to be at the same developmental stage. MDH, malate dehydrogenase (NAD-linked); other abbreviations as for Fig. 3. Despite the variation in specific activity between different samples the contrast in regulatery pattern between cap $(O)$ and stipe $(\bullet)$ is clearly evident. 


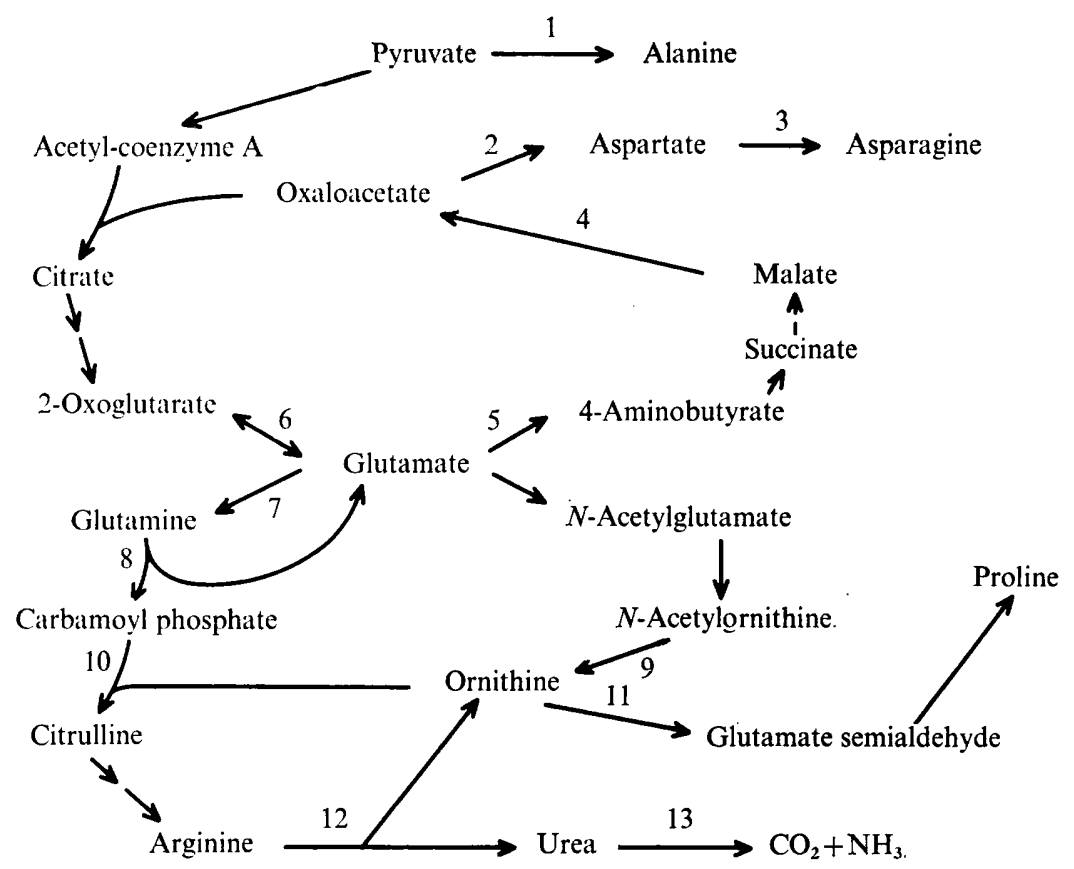

Fig. 5. Metabolic chart summarizing the reactions to which reference is made in the text. The numbers identify the enzymes involved: 1 , alanine: 2 -oxoglutarate aminotransferase; 2 , aspartate: 2 oxoglutarate aminotransferase; 3, asparagine synthetase; 4, malate dehydrogenase; 5, glutamate decarboxylase; 6, glutamate dehydrogenase; 7, glutamine synthetase; 8 , carbamoyl-phosphate synthase; 9 , ornithine acetyltransferase; 10 , ornithine carbamoyltransferase; 11 , ornithine:2-oxoacid aminotransferase, 12 , arginase; 13 , urease.

from $\mathrm{N}$-acetylornithine (Fig. 5); ornithine carbamoyltransferase catalyses the synthesis of citrulline from ornithine and carbamoyl phosphate; and glutamine synthetase is responsible for the formation of glutamine, the amide nitrogen of which may be used in the synthesis of carbamoyl phosphate if this proceeds in Coprinus cap tissue in the way described for Agaricus (Levenberg, 1962). Thus, all three enzymes can be described as contributing to arginine biosynthesis by supplying precursors. That they share the regulatory behaviour of NADP-linked glutamate dehydrogenase suggests that this enzyme also contributes to this pathway. Work with isotopically labelled substrate showed that glutamate was readily metabolized by sporophore tissue slices. After $1 \mathrm{~h}$ incubation with $\left[{ }^{14} \mathrm{C}\right]$ glutamate, $22 \%$ of the radioactivity recovered from cap tissue appeared as 4-aminobutyrate, and $54 \%$ as malate, succinate and citrate; the corresponding figures for experiments with stipe tissue were $38 \%$ and $35 \%$, respectively. These results amply confirm the suggestion made on the basis of enzymological data that the Krebs cycle in Coprinus proceeds via the glutamate decarboxylation loop (Moore \& Ewaze, 1976). It is significant that some of the isotopic label added in the form of glutamate was recovered as arginine, and that more arginine was labelled by the cap tissue ( $6 \%$ of the recovered radioactivity) than by stipe tissue $(2 \%)$.

These results show that arginine and urea synthesis were significant parts of the nitrogen metabolism of sporophore caps. Moreover, as the process leads to synthesis of urea-cycle intermediates under conditions where (urease being absent) urea was likely to accumulate, a reasonable prediction would be that urea-cycle intermediates may show a degree of accumulation in the cap. This prediction was confirmed by direct analysis, which also showed that alanine and glutamate were accumulated during development of the cap (Table 4). A variety of data showed that the urea cycle was also active in the stipe and mycelium. However, during development of the cap this aspect of metabolism was specific- 


\section{Table 4. Concentrations of some metabolites in sporophore tissues of Coprinus}

Between 4 and 13 sporophores at each stage of development were extracted in ethanol and analysed as described in Methods. Basidiospores were homogenized mechanically in ethanol until microscopic examination showed that at least $90 \%$ of the spore walls were broken.

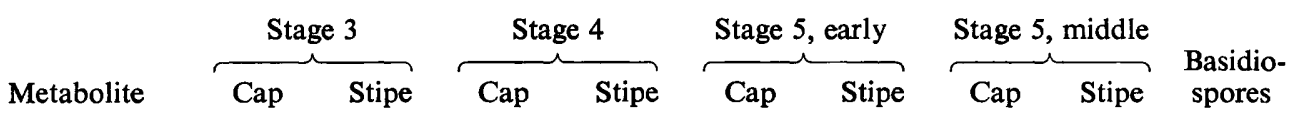

(a) quantified as $\mu \mathrm{mol}(\mathrm{g} \text { fresh } w t)^{-1}$

$\begin{array}{llllllllll}\text { Alanine } & 0.8 & 0.5 & 2.0 & 0.6 & 3.9 & 0.8 & 3.4 & 1.2 & 1.9 \\ \text { Arginine } & 2.0 & 1.8 & 2.9 & 1.3 & 4.3 & 0.8 & 3.3 & 1.3 & 0 \\ \text { Glutamate } & 1.9 & 1.4 & 1.6 & 1.5 & 3.8 & 0.9 & 3.1 & 1.0 & 0.4 \\ \text { Ornithine } & 0.5 & 0.5 & 0.6 & 0.5 & 1.1 & 0.2 & 0.5 & 0.2 & 0 \\ \text { Urea } & 2.1 & 1.2 & 2.4 & 0.9 & 2.8 & 1.1 & 2.1 & 1.0 & 2.0\end{array}$

\begin{tabular}{llllllllll} 
& \multicolumn{8}{c}{$($ ) quantified as $\mu$ mol per average sporophore } \\
Alanine & 0.34 & 0.15 & 2.15 & 0.38 & 3.19 & 0.36 & 1.66 & 0.44 & - \\
Arginine & 0.89 & 0.35 & 3.11 & 0.82 & 3.50 & 0.34 & 1.60 & 0.47 & - \\
Glutamate & 0.80 & 0.28 & 1.72 & 0.92 & 3.10 & 0.39 & 1.52 & 0.37 & - \\
Ornithine & 0.21 & 0.09 & 0.59 & 0.29 & 0.92 & 0.09 & 0.23 & 0.07 & - \\
Urea & 0.93 & 0.23 & 2.58 & 0.59 & 2.29 & 0.48 & 1.03 & 0.36 & -
\end{tabular}

ally amplified in response to unknown internal controls. Similar responses were obtained by experimental manipulation of mycelial cultures. When grown in a medium initially containing $50 \mathrm{~mm}$-glucose plus $50 \mathrm{~mm}$-ammonium tartrate, the activity of NADP-linked glutamate dehydrogenase of the monokaryon $\mathrm{BC} 9 / 6,6$ slowly increased to a maximum after $4 \mathrm{~d}$ incubation at $37^{\circ} \mathrm{C}$ (Al-Gharawi \& Moore, 1977); the same was true for ornithine acetyltransferase, ornithine carbamoyltransferase and glutamine synthetase (Fig. 6). Fawole \& Casselton (1972) showed that transfer of monokaryotic mycelium from a medium rich in amino acids into one containing $100 \mathrm{~mm}$-pyruvate, but no nitrogen source, caused considerable derepression of NADP-linked glutamate dehydrogenase by an unknown mechanism. Experiments showed that ornithine acetyltransferase, glutamine synthetase and ornithine carbamoyltransferase were also derepressed by this treatment and suggested that the control of the four enzymes was co-ordinated (Fig. 7). We have yet to analyse the regulation of these enzymes in mycelium in detail, but it is clear that inclusion of ornithine in the pyruvate transfer medium prevented the derepression, and that derepression of NADP-linked glutamate dehydrogenase in response to transfer was not coupled with any significant alteration in activity of alanine:2-oxoglutarate aminotransferase but was coupled with a decline in activity of the enzyme urease (Table 5).

These data show that, to some extent, metabolic changes which occur naturally in the sporophore cap could be reproduced in pure cultures of the vegetative mycelium. This means that the control system is open to experimental study. The regulatory circuit which is beginning to emerge has similarities with the cross-pathway regulation found in Saccharomyces (Guerzoni, 1972) and Neurospora (Carsiotis et al., 1970), while the involvement of NADP-linked glutamate dehydrogenase and glutamine synthetase may imply control systems akin to those described in Klebsiella (Magasanik et al., 1974), Saccharomyces (Dubois et al., 1973) and Aspergillus (Pateman et al., 1973) which depend at least on the activity and probably on the physical involvement of one or other of these enzyme proteins. It is too early to attempt to identify the controlling metabolites in Coprinus but already some of the complexity is evident. All four enzymes (NADP-linked glutamate dehydrogenase, glutamine synthetase, ornithine acetyltransferase and ornithine carbamoyltransferase) were derepressed considerably in the cap and, while they all showed some response to manipulation of the medium in vegetative culture, they did not respond equally to any one treatment. 


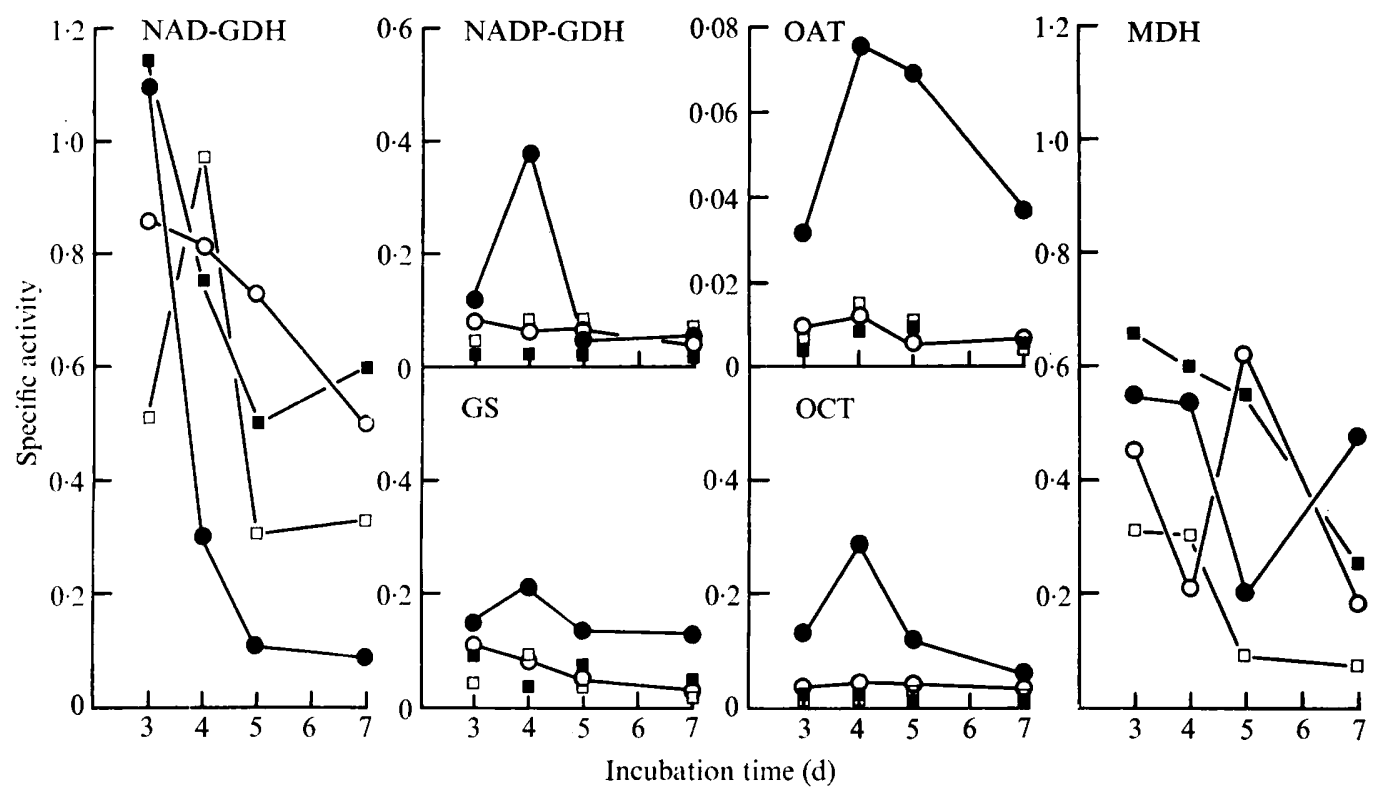

Fig. 6. Enzyme activities in monokaryotic mycelia (strain $\mathrm{BC} 9 / 6,6)$ grown in four liquid media: $50 \mathrm{~mm}$-glucose plus $50 \mathrm{~mm}$-ammonium tartrate (O); $50 \mathrm{~mm}$-glucose plus $50 \mathrm{~mm}$-urea ( $)$; $50 \mathrm{~mm}$ sodium acetate plus $50 \mathrm{~mm}$-ammonium tartrate $(O) ; 50 \mathrm{~mm}$-sodium acetate plus $50 \mathrm{~mm}$-urea ( $\square$ ). All six enzyme assays were performed with each extract. Abbreviations as in Figs 3 and 4. Note the concerted regulatory response to growth in glucose/ammonium medium of the enzymes NADP-GDH, OAT, GS and OCT.

Table 5. Specific activities of selected enzymes in mycelia of the monokaryon $\mathrm{BC} 9 / 6,6$ before and after transfer to defined experimental media

Mycelia were grown on an orbital shaker at $37^{\circ} \mathrm{C}$ in liquid medium containing $1 \%(\mathrm{w} / \mathrm{v})$ casein hydrolysate, $30 \mathrm{~mm}-\mathrm{NH}_{4} \mathrm{Cl}$ and $10 \mathrm{~mm}$-glucose. After $4 \mathrm{~d}$ the tissue was harvested by centrifuging and washed with water. Enzymes were assayed immediately in one sample (initial control); other samples were resuspended in defined media as indicated and re-incubated before final harvesting and extraction. Specific activities are expressed as nmol substrate utilized $\min ^{-1}$ (mg protein) ${ }^{-1}$.

\begin{tabular}{ccccccccc} 
& \multicolumn{110}{c}{ Enzyme** } & & NAD- & MDH \\
Treatment & Urease & GDH & GS & OAT & OCT & GPT & GDH & MDP- \\
Initial control & 8.0 & 30 & 20 & 8 & 10 & 80 & 370 & 960
\end{tabular}

(a) Mycelium transferred to medium containing $100 \mathrm{~mm}$-pyruvate without nitrogen source and reincubated for:

$\begin{array}{rllllllll}3 \mathrm{~h} & 7 \cdot 7 & 130 & 140 & 17 & \text { ND } & 60 & 420 & 720 \\ 18 \mathrm{~h} & 2 \cdot 1 & 270 & 340 & 27 & 30 & 40 & 350 & 590 \\ 24 \mathrm{~h} & 1 \cdot 7 & 180 & 440 & 22 & 10 & 40 & 150 & 590\end{array}$

(b) Mycelium re-incubated for $18 \mathrm{~h}$ after transfer to medium containing:

$\begin{array}{lllllllll}50 \text { mM-Ornithine } & 1 \cdot 6 & 20 & 80 & 11 & 10 & 40 & 370 & 740 \\ 100 \text { mM-Pyruvate }+ & 2 \cdot 3 & 30 & 80 & 14 & 10 & 80 & 180 & 390\end{array}$

50 mM-Ornithine

ND, Not determined.

* NAD-GDH and NADP-GDH, NAD- and NADP-linked glutamate dehydrogenases; GS, glutamine synthetase; OAT, ornithine acetyltransferase; OCT, ornithine carbamoyltransferase; GPT, alanine:2-oxoglutarate aminotransferase; $\mathrm{MDH}$, malate dehydrogenase. 

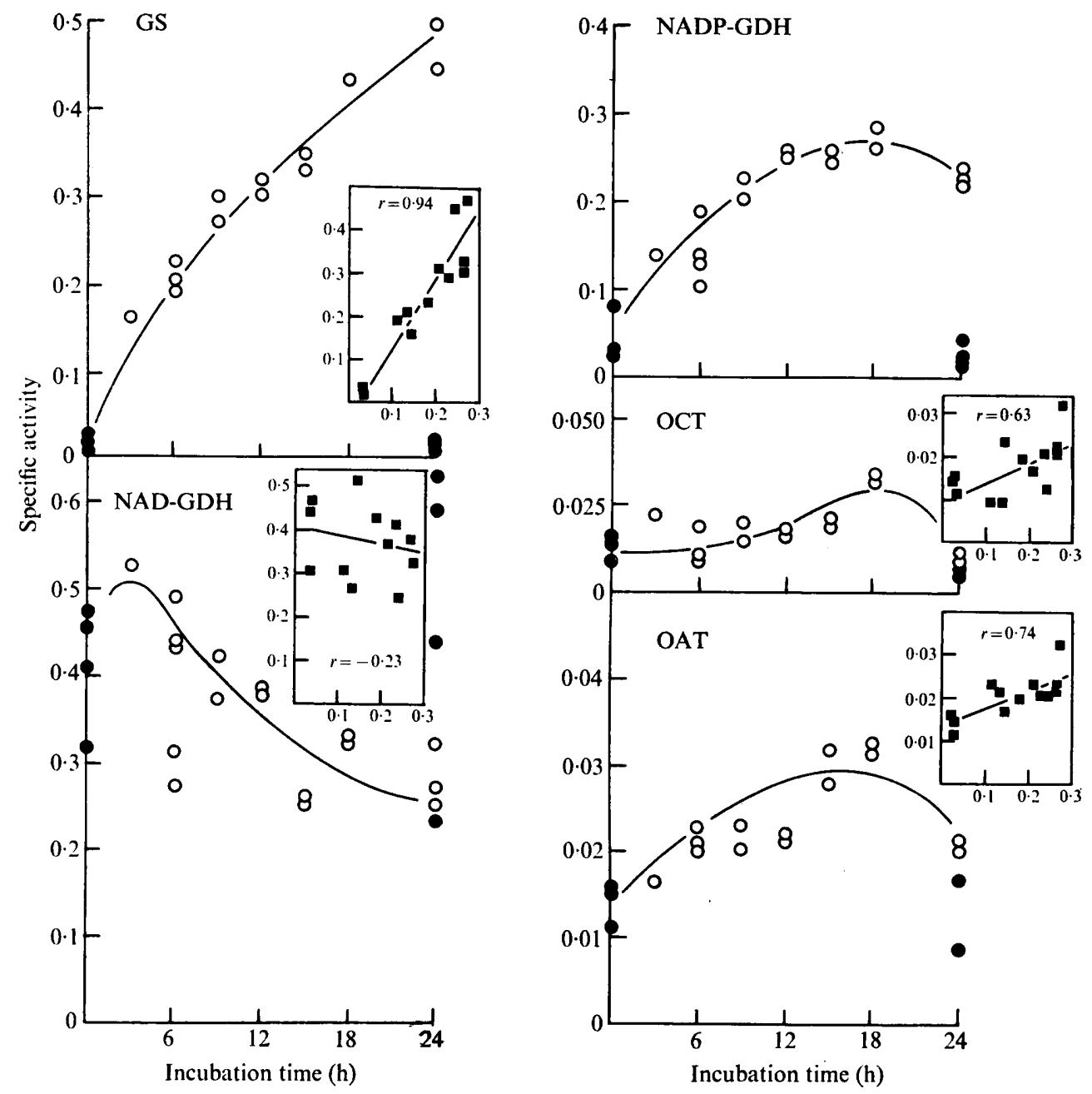

Fig. 7. Enzyme activities in monokaryotic mycelia (strain BC9/6,6) transferred from a medium rich in amino acids to a defined medium lacking nitrogen source but containing $100 \mathrm{~mm}$-pyruvate as sole carbon source. Symbols indicate enzyme activities at the time of transfer (time zero in these plots) by which time the mycelia had been grown for $4 \mathrm{~d}$ in the original medium, and are also used to show activities in mycelia incubated in the original medium for a further $24 \mathrm{~h}$ without transfer. Inset plots $(\square)$ compare the specific activity of the indicated enzyme with that of NADP-GDH in the same homogenate; linear regression lines are drawn and $r$ is the correlation coefficient.

Ornithine carbamoyltransferase showed a threefold derepression in glucose plus ammonium medium (Fig. 6) but only a $50 \%$ increase in the pyruvate-transfer experiment (Fig. 7); in contrast, glutamine synthetase activity increased by only $30 \%$ in the former type of medium (Fig. 6), but had a 50-fold increase in the latter experiment (Fig. 7). Table 5 contains another example: the decline in urease activity that occurred in response to transfer to pyruvate medium appears to be very closely related to the increase in activity of, for example, NADP-linked glutamate dehydrogenase and this certainly correlates with events in the cap; yet, although inclusion of ornithine in the transfer medium prevented the increase in NADP-linked glutamate dehydrogenase activity, it did not arrest the decline in urease activity.

It is clear that during cap development the urea-cycle activity is amplified while urea dissimilation is curtailed. If disposal of excess nitrogen is the main function of the urea cycle, 
Table 6. Specific activities of carbamoyl-phosphate synthase in homogenates of sporophore tissues

Sporophores in stage 5 were dissected and cap and stipe tissues were homogenized separately. The homogenates were desalted on a column of Sephadex G-25 prior to assay. The assay (detailed in Methods) measures the acid-fast fixation of ${ }^{14} \mathrm{CO}_{2}$ in a mixture containing an excess of ornithine and ornithine carbamoyltransferase; the product is presumed to be citrulline. In this experiment the identity of the nitrogen donor was varied. Specific activities are expressed as $\mu \mathrm{mol}{ }^{14} \mathrm{CO}_{2}$ fixed $\min ^{-1}(\mathrm{mg} \text { protein })^{-1}$.

\begin{tabular}{|c|c|c|}
\hline Nitrogen donor & Cap & Stipe \\
\hline 10 mm-Glutamine & $0 \cdot 15$ & 0.31 \\
\hline $50 \mathrm{~mm}$-Ammonium sulphate & $0 \cdot 14$ & 0.22 \\
\hline $\begin{array}{l}10 \mathrm{~mm} \text {-Glutamine }+ \\
50 \mathrm{~mm} \text {-Ammonium sulphate }\end{array}$ & $0 \cdot 11$ & ND \\
\hline $\begin{array}{l}10 \text { mM-Glutamine }+ \\
5 \mathrm{~mm}-N \text {-Acetylglutamate }\end{array}$ & $0 \cdot 13$ & ND \\
\hline $\begin{array}{l}50 \mathrm{~mm} \text {-Ammonium sulphate }+ \\
5 \mathrm{~mm}-N \text {-Acetylglutamate }\end{array}$ & $0 \cdot 19$ & ND \\
\hline $\begin{array}{l}50 \text { mM-Ammonium sulphate }+ \\
10 \mathrm{~mm} \text {-Glutamine }+ \\
5 \mathrm{~mm}-N \text {-Acetylglutamate }\end{array}$ & $0 \cdot 13$ & ND \\
\hline
\end{tabular}

the absence of urease from the cap is paradoxical. Coincident derepression of NADP-linked glutamate dehydrogenase and glutamine synthetase can be interpreted as being a response to the need to aminate under conditions of ammonia limitation both in sporophore cap (Fig. 2) and in mycelium (Fig. 7), rather like the glutamate synthase-glutamine synthetase mechanism identified in yeasts (Brown \& Johnson, 1970; Brown et al., 1973; Burn et al., 1974), bacteria (Tempest et al., 1973) and other organisms. If ammonia were made available to cap tissues this response could be negated, but it would be futile to suggest that urease is repressed to avoid ammonia interference with ammonia-limited amination. Derepression of NADP-linked glutamate dehydrogenase and glutamine synthetase is not essential to operation of the urea cycle; the cycle operates effectively in the stipe. Indeed, in crude extracts at least, carbamoyl-phosphate synthase seems to be able to make equally effective use of either glutamine or ammonia (Table 6). But urease activity releases $\mathrm{CO}_{2}$ as well as ammonia, and it is possible that the contrary regulation of urease in cap and in stipe is related to different morphogenetic effects exerted by this compound. Although not yet established for Coprinus, in Agaricus it is clear that high $\mathrm{CO}_{2}$ concentrations promote stipe elongation whereas cap enlargement is enhanced by lowered $\mathrm{CO}_{2}$ concentrations (Turner, 1977).

Whatever the causality of the urease regulation, the outcome is an accumulation of urea and other precursors. These accumulations were estimated by extraction of total ethanolsoluble material, and so interpretation may be complicated by intracellular compartmentations not revealed by this approach. Nevertheless, functions can be ascribed to some of the accumulated metabolites. By analogy with data from Neurospora (Weiss, 1973, 1976), compartmentation of arginine is particularly likely, but, providing it does represent an increase in concentration in the environment of the enzyme, the accumulation of arginine recorded in Table 4 can be interpreted as a means by which the activity of arginase is regulated. From the kinetic properties of the enzyme (Table 1), it can be calculated that the flux through the arginase reaction is likely to increase by a factor of at least two to three in the cap while declining in the stipe as development proceeds from stage 3 (immature sporophore, post-meiotic, spore formation just starting) to stage 5 (mature sporophore dis- 
charging spores). Indeed, the arginine accumulation will lead to a sixfold higher flux through the arginase reaction in the cap than in the stipe even though there is little difference between the specific activities of arginase in the two tissues (Fig. 3). Increased concentrations of alanine and glutamate may represent enlarged pools of compounds arising from transamination reactions and could be a reflection of the heightened amino-metabolism activity. But it should be noted that glutamate at high concentration acts as an allosteric activator of NADP-linked glutamate dehydrogenase in vitro and could well serve as a regulator of this enzyme activity in vivo (Al-Gharawi \& Moore, 1977). The most interesting of the compounds that accumulated is urea. This was the only compound which increased considerably in total quantity as the sporophore developed, although its concentration on a unit fresh weight basis (Table 4) remained virtually unchanged. We take this to mean that accumulation of urea was accompanied by the (osmotic) absorption of water. The functional significance here seems to lie in the cell enlargement which occurs during development of the gills (M. M. Y. Elhiti, unpublished results). Cap expansion in Coprinus has received remarkably little attention; because stipe growth is such a dramatic feature of the final 10 to $16 \mathrm{~h}$ of the developmental sequence, much of the work so far done has concentrated on this aspect (Gooday, 1974; Craig et al., 1977). However, during this phase of rapid stipe growth the cap progresses through an equally dramatic development during which the initially vertical gill orientation is transformed to a horizontal one within about $6 \mathrm{~h}$.

In reference to Coprinus comatus, Buller (1931) remarked on the paucity of pileal flesh in relation to the amount of gill tissue in coprinoid caps and commented on the mechanical problem of supporting the gills as they expand. The problem is lessened if inflation of the paraphyses enables them to contribute both to the support and the load. If the pileal flesh is assumed to act as an inextensible but flexible outer border to each gill, then the increase in area of the gill plate which is a consequence of the inflation of individual cells of the paraphyseal pavement will inevitably lead to reflection and erection of the gills. The infiated cells do not have strengthened walls but they do have much enlarged vacuoles (M. M. Y. Elhiti, unpublished results). We believe that the cell enlargement observed as the cap expands is produced by the osmotic influx of water, that this is a response to urea accumulation, and that to provide for this urea accumulation NADP-linked glutamate dehydrogenase, glutamine synthetase, ornithine acetyltransferase and ornithine carbamoyltransferase (and presumably other enzymes) are co-ordinately derepressed during sporophore development.

\section{REFERENCES}

Abdumalikov, A. K. \& Nikolaev, A. Y. (1967). Separation and purification of glutaminase, asparaginase and isoglutamine desamidase from yeast. Biokhimiia 32, 713-719.

Al-Gharawi, A. \& Moore, D. (1974). Effects of D-glutamate on mycelial growth and glutamate dehydrogenase enzymes of Coprinus lagopus. Journal of General Microbiology 85, 274-282.

Al-Gharawi, A. \& Moore, D. (1977). Factors affecting the amount and the activity of the glutamate dehydrogenases of Coprinus cinereus. Biochimica et biophysica acta 496, 95-102.

ARChIBALD, R. M. (1944). Determination of citrulline and allantoin and demonstration of citrulline in blood plasma. Journal of Biological Chemistry 156, 121-142.

Brown, C. M. \& Johnson, B. (1970). Influence of the concentration of glucose and galactose on the physiology of Saccharomyces cerevisiae in continuous culture. Journal of General Microbiology 64, 279-287.

Brown, C. M., Burn, V. J. \& Johnson, B. (1973).
Presence of glutamate synthase in fission yeasts and its possible role in ammonia assimilation. Nature New Biology 246, 115-116.

BuLler, A. H. R. (1931). Researches on Fungi, vol. 4. London: Longman, Green \& Co.

Burn, V. J., Turner, P. R. \& Brown, C. M. (1974). Aspects of inorganic nitrogen assimilation in yeasts. Antonie van Leeuwenhoek 40, 93-102.

Carsiotis, M., Jones, R. F., LaCy, A. M., Cleary, T. J. \& FANKhaUSER, D. B. (1970). Histidinemediated control of tryptophan biosynthetic enzymes in Neurospora crassa. Journal of Bacteriology 104, 98-106.

ChInARD, F. P. (1952). Photometric estimation of proline and ornithine. Journal of Biological Chemistry 199, 91-95.

Craig, G. D., Gull, K. \& Wood, D. A. (1977). Stipe elongation in Agaricus bisporus. Journal of General Microbiology 102, 337-347.

DARBYShIRE, J. (1974). Developmental studies on Coprinus lagopus (sensu Buller). Ph.D. thesis, Manchester University. 
Dubois, E., Grenson, M. \& Wiame, J. M. (1973). Release of the 'ammonia effect' on three catabolic enzymes by NADP-specific glutamate dehydrogenaseless mutations in Saccharomyces cerevisiae. Biochemical and Biophysical Research Communications 50, 967-972.

Fawole, M. O. \& Casselton, P. J. (1972). Observations on the regulation of glutamate dehydrogenase activity in Coprinus lagopus. Journal of Experimental Botany 23, 530-551.

GoODAY, G. W. (1974). Control of development of excised fruit bodies and stipes of Coprinus cinereus. Transactions of the British Mycological Society 62, 391-399.

Guerzoni, M. E. (1972). Physiological and enzymatic aspects of histidine-mediated control of the tryptophan pathway. Archiv für Mikrobiologie 86, 57-68.

LEVENBERG, B. (1962). Role of L-glutamine as donor of carbamyl nitrogen for the enzymatic synthesis of citrulline in Agaricus bisporus. Journal of Biological Chemistry 237, 2590-2598.

Lowry, O. H., Rosebrough, N. J., FArR, A. L. \& RANDALL, R. J. (1951). Protein measurement with the Folin phenol reagent. Journal of Biological Chemistry 193, 265-275.

Magasanik, B., Prival, M. J., Brenchley, J. E., Tyler, B. M., Deleo, A. B., Streicher, S. L., Bender, R. A. \& Paris, C. G. (1974). Glutamine synthetase as a regulator of enzyme synthesis. Current Topics in Cellular Regulation 8, 119-138

Moore, D. \& Ewaze, J. O. (1976). Activities of some enzymes involved in metabolism of carbohydrate during sporophore development in Coprinus cinereus. Journal of General Microbiology 97, 313-322.

NeLSON, N. (1944). A photometric adaptation of the Somogyi method for the determination of glucose. Journal of Biological Chemistry 153, 375-380.

Orebamjo, T. O. \& Stewart, G. R. (1974). Some characteristics of nitrate reductase induction in Lemna minor L. Planta 117, 1-10.

OSBORNE, D. J. (1962). Effect of kinetin on protein and nucleic acid metabolism of Xanthium leaves during senescence. Plant Physiology 37, 595-602.

Pateman, J. A., Kinghorn, J. R., Dunn, E. \& Forbes, E. (1973). Ammonium regulation in Aspergillus nidulans. Journal of Bacteriology 114, 943-950.

Ravel, J. M., Norton, S. J., Humphreys, J. S. \& SHIVE, W. (1962). Asparagine biosynthesis in Lactobacillus arabinosus and its control by asparagine through enzyme inhibition and repression. Journal of Biological Chemistry 237, 2845-2849.
Roon, R. J. \& LeVenberg, B. (1968). An ATPdependent, avidin-sensitive enzymatic cleavage of urea in yeast and green algae. Journal of Biological Chemistry 243, 5213-5215.

Roon, R. J. \& LeVEnBerg, B. (1972). Urea amidolyase. I. Properties of the enzyme from Candida utilis. Journal of Biological Chemistry 247, 41074113.

Schimke, R. T. (1970). Arginine deiminase (Mycoplasma). Methods in Enzymology 17A, 310-313.

Staub, M. \& Denes, G. (1966). Mechanism of arginine biosynthesis in Chlamydomonas reinhardii. 1. Purification and properties of ornithine acetyltransferase. Biochimica et biophysica acta 128, 82-91.

Stewart, G. R. \& Moore, D. (1974). The activities of glutamate dehydrogenases during mycelial growth and sporophore development in Coprinus lagopus (sensu Lewis). Journal of General Microbiology 83, 73-81.

Tempest, D. W., Meers, J. L. \& Brown, C. M. (1973). Glutamate synthase (GOGAT); a key enzyme in the assimilation of ammonia by prokaryotic organisms. In The Enzymes of Glutamine Metabolism, pp. 167-182. Edited by S. Prusiner \& E. R. Stadtman. New York: Academic Press.

TuRNER, E. M. (1977). Development of excised sporocarps of Agaricus bisporus and its control by $\mathrm{CO}_{2}$. Transactions of the British Mycological Society 69, 183-186.

Vogel, H. J. \& BonNer, D. M. (1956). Acetylornithinase of Escherichia coli: partial purification and some properties. Journal of Biological Chemistry 218, 97-106.

Vogel, R. H. \& Kopac, M. J. (1960). Some properties of ornithine transaminase from Neurospora. Biochimica et biophysica acta 37, 539-540.

WEISS, R. L. (1973). Intracellular localization of enzymes of arginine metabolism in Neurospora. Journal of Biolugical Chemistry 248, 5403-5408.

WeIss, R. L. (1976). Compartmentation and control of arginine metabolism in Neurospora. Journal of Bacteriology 126, 1173-1179.

Woolfolk, C. A., Shapiro, B. \& Stadtman, E. R. (1966). Regulation of glutamine synthetase. I. Purification and properties of glutamine synthetase from Escherichia coli. Archives of Biochemistry and Bivphysics 116, 117-192.

Yellin, T. O. \& Wriston, J. C. (1966). Purification and properties of guinea pig serum asparaginase. Biochemistry 5, 1605-1612. 